\title{
Peritoneal carcinomatosis in animal model
}

\section{동물을 이용한 복막전이모델}

Department of Surgery, The Catholic University of Korea College of Medicine, Seoul, Korea In Kyu Lee, M.D

가톨릭대학교 의과대학 외과학교실 이 인 규

\section{서 론}

복강 내 종양의 파종에 대한 연구는 임상적 연구로는 윤리적인 문제 때문에 시행이 어려우므로 수술 후 종양의 파종에 따른 시 간적 추이나 어떠한 복강내 수술적 환경이 이러한 종양의 파종을 증진시키는지에 대한 연구는 동물모델에서나 가능하며, 인간의 생리적 조건과 근접할수록 동물모델로서 좋은 결과를 얻을 수 있 다. 이 글에서는 외과종양학적 영역에서 시행되고 설치류를 이용 한 동물모델에 대해 논하고자 한다.

\section{본 론}

동물을 이용한 전이모델에는 전이되는 기관에 따라 다양한 방법 으로 동물모델을 만들고 있다. 폐전이를 위해서는 tail vein을 이 용하거나 간전이를 위해서는 비장을 통한 종양세포의 주입을 통 해 전이를 유발한다. 복막전이의 경우에는 그 보다 간단하여 단 순히 복강내 세포의 주입을 통해 만들 수 있다. 그 외에 전형적인 전이를 보는 방법으로는 대장암에 있어 대장암 세포주를 대장벽 에 주입하여 임파관 및 간, 폐, 복막전이를 유발하는 방법을 사용 하고 있다. 사용하는 종양세포에 따라 동종의 종양세포를 주입하 는 경우나 인간의 종양세포를 누드마우스에 주입하는 경우로 나 눌 수가 있다. 대장암 세포주를 이용한 각 기관의 전이모델과 복 막전이모델을 이용한 연구는 다음과 같다.

\section{책임저자 : 이인규}

150-713 서울특별시 영등포구 여의도동 62 여의도성모병원 외과 Tel: 02-3779-2235 Fax: 02-786-0802 E-mail: cmcgslee@catholic.ac.kr 접수일 : 2010년 5월 20일 ; 게재승인일 : 2010년 6월 23일

\section{1) Tail vein을 이용한 폐 전이 모델}

Balb/c wild type mouse 2.5X104 CT26 마우스 대장암 세포주 를 tail vein 에 주입 후 2-4주 후 폐를 절제하여 Bouin's solution에 고정하여 관찰한다.

\section{2) 비장을 이용한 간 전이 모델}

C57BL/6 마우스의 midline incision을 통해 비장을 밖으로 꺼낸 후1X105 동종 MC38 대장암 세포주를 비장의 장막하에 주입 후 bovie를 이용하여 coagulation 및 증류수 세척을 시행한 후 2 분 후 비장절제술을 시행함으로써 간 전이를 유발 하고 14 일 후 간 을 절제하여 간의 전이를 확인한다. ${ }^{2}$

\section{3) 대장암 세포주의 동소자리 미세주입을 통한 전이 유발 모델}

인간의 대장암 세포주(HCT-116, SW-620,, DLD-1)를 이용하 여 4주된 수컷의 Swiss $\mathrm{Nu} / \mathrm{Nu}$ 마우스에 250- $\mu \mathrm{m}$ 지름의 pipette을 이용하여 점막과 점막근육층에 세포를 주입함으로써 4-8주 후에 전이를 야기하는 orthotopic cell microinjection (동소자리 세포미세주입) 동물모델은 tail vein이나 footpad에 주입함으로써 전이를 유발하는 모델의 비생리적이며 거의 한군 데에 전이를 유발하는 동물모델에 비해 생리적이면서 특별한 처 치 없이 모든 장소에 전이가 생성되므로 전이 연구에 유용한 방 법이다. ${ }^{3)}$

\section{4) colon carcinogenesis 동물 모델}

Colon carcinogenesis의 설치류 모델은 크게 유전자적 조작을 통해 저절로 carcinogenesis가 일어나는 유전자 모델(genetic model)과 화학적물질에 의한 carcinogen 유발 모델이 있다. 유전자 모델로 APC homologue의 codon 850의 mutation 을 
가지고 있는 multiple intestinal neoplasia (Min) mouse (Apc $\mathrm{Min}, \mathrm{C} 57 \mathrm{BL} 6 / \mathrm{J})$ 모델은 소장에 30개 가량의 용종이 생기며 이 로 인하여 빈혈과 악액질이 생겨 평균 120 일 정도 생존한다. ${ }^{4)}$ 유 사한 모델로 codon 716 mutation 을 동반하는 Apc $\Delta 716$ 은 보 다 많은 선종과 장 이외 기관에서의 증상이 나타난다. ${ }^{5}$

Carcinogen induced model로는 쥐나 마우스에서는 자연적으 로 대장암이 잘 발생하지 않으므로 1,2-dimethylhydrazine (DMH)나 이것의 대사물인 azoxymethane (AOM)이 가장 흔히 대장암 유발 carcinogen으로 사용된다(AOM/DMH model). 이 동물 모델은 인간의 대장암 carcinogenesis와 유사한 multistep process 나 Wnt signalling의 변화나 K-RAS mutation이 발견 된다. ${ }^{4)}$ 이러한 두 모델은 인간의 대장암 carcinogenesis 와 비슷 하기 때문에 chemopreventive activity를 확인하는 데 많이 사 용되고 있다.

\section{5) 복막전이에 대한 수술적 영향을 알기 위한 동물 모델}

동종세포주를 이용한 복강내 암세포 주입을 통한 복강내 전이를 만든 후 이에 영향을 미치는 요소나 항암치료의 효과 등을 보는 연구가 시행되고 있다. 최근들어 암 수술의 방법으로 인정되고 있는 복강경 수술의 영향에 대한 연구가 이루어지고 있다. $\mathrm{CO}_{2}$ 를 이용한 기복이 복막전이에 미치는 영향에 대한 연구에서는 C57BL6 마우스와 마우스 난소암 세포주 (ID8)을 이용한 실험모 델이 사용되고, 이 연구에서는 복압과 마취 방법에 따른 복막전 이를 보는 동물모델을 이용하고 있다. ${ }^{6.7)}$ 이런 연구를 통해 복압 의 증가 $(8 \mathrm{mmHg}$ vs. $2 \mathrm{mmHg})$ 는 마우스모델에서 복강내 전이 를 증가시키고 기전으로는 산성화는 암의 전이나 종양의 성장에 영향을 미치며 복압의 상승된 경우에는 이러한 전신의 산성화가 진행되므로 이러한 복압의 증가가 전이에 미치는 영향을 설명하 고 있다.6)

\section{6) 복막전이에 대한 치료적 효과를 알기 위한 동물 모델}

12 주 $\mathrm{BD} \mathrm{IX}$ 쥐 모델을 이용하여 $\mathrm{DMH}$ 에 의해 동종의 쥐에서 유 발된 대장암 세포주인 DHD/K12을 주입하여 복막암을 유발하고 matrix metalloproteinases inhibitor (batimastat)와 같은 실 험 약제를 초기 또는 후기에 투여하여 약제의 전이 억제 능력을 확인하거나, ${ }^{8)}$ 외과나 산부인과 영역에서는 온열화학요법을 많이 시행하고 있으나 비뇨기과 영역에서는 흔히 사용되지 않기 때문 에 Fischer 344 쥐를 이용하여 transitional cell carcinomatosis 를 유발하는 AY-27 세포주를 106 주입하여 carcinomatosis 를
유발한 후 항암제 mitomycin C 투여의 시기적 효과나 surgical debulking의 효과를 확인하기 위한 동물모델로 사용하고 있다. ${ }^{9}$

\section{7) 창상을 이용한 복막전이 동물 모델}

본 저자의 경우 대장암의 복막전이에 대한 임상적 데이터를 바탕 으로 하여 이에 대한 이론적 근거를 찾기 위하여 창상을 이용한 복막전이 동물 모델을 만들었고 이에 대한 실험 방법은 다음과 같다. 8 주된 $\mathrm{C} 57 \mathrm{bl} / 6 \mathrm{~J}$ 수컷 마우스를 이용하여 전이성 종양은 동 종의 MC38 마우스 대장암세포주을 복막에 injection 하여 만들 었으며 복부에 창상이 미치는 영향을 확인하기 위해 복부에 창상 을 $1.5 \mathrm{~cm}$ 크기로 만들어 prolene 4-0를 이용해 5 stitch, continuous running suture 봉합한 후 peritoneal injection은 $100 \mathrm{ul}, 1 \mathrm{x} 105$ cells과 $900 \mathrm{ul}$ PBS을 복강내 우측하방에 $25 \mathrm{G}$ 주 사기를 이용하여 주입하며 마우스를 각각 4 개의 군으로 구분하 여 아래의 Table 1 과 같은 스케줄로 실험을 한다

\section{Table 1.}

\begin{tabular}{lccc}
\hline & Surgery & Injection & Endpoint \\
\hline Control Group & None & None & 3 months old \\
Injection Group & None & D 0 & POD 21 \\
Early Wound Group & Abdominal Incision & POD 0 & POD 3 \\
Wound Group & Abdominal Incision & POD 0 & POD 21 \\
Delay Group & Abdominal Incision & POD 7 & POD 28 \\
\hline
\end{tabular}

\section{결 론}

동물을 이용한 실험모델은 앞에서 언급한 바와 같이 임상적으로 하기 어려운 연구에 대한 대체방안이다. 또한 임상적으로 얻은 지식을 동물 연구를 통해 이 지식의 기본적인 근거를 확인 할 수 있으며 새로운 치료 약제나 치료 방법을 시험할 수 있는 방법이 다. 외과의사의 경우 수술기법에 익숙하므로 동물실험을 잘 시행 할 수 있으며, 수술을 통해 얻은 경험을 동물 실험을 통해 체계화 할 수 있으므로 많은 도움을 얻을 수 있다. 하지만 최근에는 동물 실험에 대한 많은 규제가 있으므로 이에 대한 사전 지식이 필요 하다.

\section{REFERENCES}

1. Chen $X$, Su Y, Fingleton B, Acuff $H$, Matrisian LM, Zent R, Pozzi A.Increased plasma MMP9 in integrin alpha1-null mice enhances lung metastasis of colon carcinoma cells. Int J Cancer. 2005 Aug 10;116(1):52-61.

2. Gorden $D L$, Fingleton $B$, Crawford $H C$, Jansen $D E$, Lepage $M$, 
Matrisian LM.Resident stromal cell-derived MMP-9 promotes the growth of colorectal metastases in the liver microenvironment.Int J Cancer. 2007 Aug 1;121(3):495-500.

3. Céspedes MV, Espina C, García-Cabezas MA, Trias M, Boluda A, Gómez del Pulgar MT, Sancho FJ, Nistal M, Lacal JC, Mangues R. Orthotopic microinjection of human colon cancer cells in nude mice induces tumor foci in all clinically relevant metastatic sites. Am J Pathol. 2007 Mar;170(3):1077-85.

4. Femia AP, Caderni G. Rodent models of colon carcinogenesis for the study of chemopreventive activity of natural products. Planta Med 2008;74:1602-7

5. Gaspar C, Fodde R. APC dosage effects in tumorigenesis and stem cell differentiation. Int J Dev Biol 2004;48:377-86

6. Bourdel N, Matsuzaki S, Bazin JE, Darcha C, Pouly JL, Mage G, Canis M. Postoperative peritoneal dissemination of ovarian cancer cells is not promoted by carbon-dioxide pneumoperitoneum at low intraperitoneal pressure in a syngenic mouse laparoscopic model with controlled respiratory support: a pilot study.J Minim Invasive Gynecol. 2008 May-Jun;15(3):321-6. Epub 2008 Mar 20

7. Matsuzaki S, Bourdel N, Darcha C, Déchelotte PJ, Bazin JE, Pouly JL, Mage G, Canis M Molecular mechanisms underlying postoperative peritoneal tumor dissemination may differ between a laparotomy and carbon dioxide pneumoperitoneum: a syngeneic mouse model with controlled respiratory support. Surg Endosc. 2009 Apr;23(4):705-14. Epub 2008 Jul 12.

8. Aparicio T, Kermorgant S, Dessirier V, Lewin MJ, Lehy T. Matrix metalloproteinase inhibition prevents colon cancer peritoneal carcinomatosis development and prolongs survival in rats. Carcinogenesis. 1999 Aug;20(8):1445-51.

9. Abaza R, Miocinovic R, Keck RW, Selman SH. Prevention and treatment of transitional cell carcinomatosis with intraperitoneal chemotherapy in a rat model.J Urol. 2009 Apr;181(4):1901-6. Epub 2009 Feb 23. 